\title{
ANALISIS TEMUAN PATROLI POLISI HUTAN TERHADAP PERBURUAN SATWA LIAR DI RESORT WAY KANAN, TAMAN NASIONAL WAY KAMBAS
}

\author{
Analysis of Findings the Forest Ranger Patrol's Findings on Wildlife Hunting at the \\ Way Kanan Resort, Way Kambas National Park
}

\section{Zaqi Maula Zamzami*, Gunardi Djoko Winarno, Yulia Rahma Fitriana, Irwan Sukri \\ Banuwa}

\author{
Jurusan Kehutanan, Fakultas Pertanian, Universitas Lampung \\ Jln. Prof. Dr. Soemantri Brojonegoro No. 1 Gedung Meneng, Bandar Lampung \\ *Email : zaqimaulaz16@gmail.com
}

Diterima: 06/11/2020, Direvisi: 10/06/2021, Disetujui: 16/06/2021

\begin{abstract}
Hunting for wildlife in Way Kambas National Park (WKNP) is one of the leading causes of humans and animal conflict. So far, patrol activities are still considered less than optimal because of the decline in animal populations due to frequent hunting. This study aimed to analyze the findings of forest ranger patrols in protecting wild animals from hunting in WKNP. Data collection was carried out by observation, interviews and literature study. The data collected from the literature were then analyzed descriptively qualitatively. The results showed that during patrol activities, the finding of snares was still very much used by hunters and also found elephants that died due to hunting, although the range of forest rangers every year had increased but the number of personnel who did not match the size of the forest area made some areas not can be protected.
\end{abstract}

Keywords; Way Kambas National Park, Wildlife, Forest Range Forest Protection, Wildlife Hunting.

\section{ABSTRAK}

Perburuan satwa liar di Taman Nasional Way Kambas (TNWK) merupakan salah satu penyebab utama terjadinya konflik antara manusia dan satwa. Sejauh ini kegiatan patroli masih dirasa kurang optimal karena penurunan populasi satwa akibat perburuan masih sering terjadi. Tujuan dari penelitian ini menganalisis temuan patroli polisi hutan dalam melindungi satwa liar dari perburuan di TNWK. Pengumpulan data dilakukan dengan observasi, wawancara dan studi literatur. Data yang terkumpul dari kepustakaan kemudian dianalisis secara deskriptif kualitatif. Hasil penelitian menunjukan bahwa pada saat kegiatan patroli temuan jerat masih sangat banyak digunakan oleh pemburu dan ditemukan juga satwa gajah yang mati akibat perburuan, meskipun daya jelajah patroli polisi hutan setiap tahunnya mengalami kenaikan tetapi jumlah personil yang tidak sesuai dengan luasnya kawasan hutan membuat beberapa wilayah tidak dapat terlindungi.

Kata kunci; Taman Nasional Way Kambas, Satwa Liar, Polisi Hutan, Perlindungan Hutan, Perburuan Satwa Liar. 


\section{PENDAHULUAN}

Satwa liar merupakan salah satu komponen ekosistem, jenis-jenis satwa liar, sebagai individu atau kelompok, mempunyai peran dalam menjaga keseimbangan proses di alam. Dengan demikian, kelangsungan kehidupan satwa akan tergantung satu sama lain; dan penurunan populasi salah satu di antaranya akan berdampak negatif terhadap kesinambungan jaring-jaring makanan dan menghambat kelancaran arus dan siklus energi sehingga akan memicu masalah ekologis (Mallawi, 2010, Sunarto, 2013). Menurut Alikodra (1990) satwa liar dapat diartikan binatang yang hidup liar di alam bebas tanpa campur tangan manusia. Dalam ekosistem alam, satwa liar memiliki peranan yang sangat banyak dan penting, salah satunya adalah untuk melestarikan hutan.

Perburuan dan perdagangan satwa liar merupakan bentuk eksploitasi sumber daya alam tanpa memperhatikan kelestarian lingkungan. Kerusakan hutan ini telah mengganggu proses alam, sehingga banyak fungsi ekologi alam terganggu. Faktor-faktor yang mempengaruhi kepunahan satwa liar selain degradasi hutan adalah perburuan dan perdagangan satwa, di mana populasi suatu spesies menurun akan mengakibatkan rantai makanan terputus. Selain kepunahan satwa dampak lainnya akibat ketidakseimbangan ekosistem disuatu habitat adalah konflik satwa liar (Prayudhi, 2015). Perburuan satwa liar di Taman Nasional Way Kambas (TNWK) adalah salah satu penyebab utama terjadinya konflik antara manusia dan satwa khususnya gajah (Pratiwi et al., 2020). Gangguan manusia berupa penyempitan habitat dan perburuan dapat menyebabkan penurunan populasi satwa liar secara drastis atau wilayah teritorial satwa liar semakin sempit sehingga intensitas penurunan populasi satwa semakin meningkat dari tahun ke tahun (Nugroho et al., 2008).

Peran patroli hutan sangat penting sebagai bagian dari kegiatan pengelolaan hutan (Dirjen PHKA. 2011) namun kegiatan patroli masih dirasa kurang optimal. Hal ini diakibatkan karena penurunan populasi satwa akibat perburuan tersebut masih terjadi. Menurut Zain (2000) polisi kehutanan merupakan salah satu pihak yang bertanggung jawab atas pengamanan hutan khususnya perburuan satwa liar. Tugas pokok polisi kehutanan adalah menyiapkan, melaksanakan, mengembangkan, memantau, dan mengevaluasi serta melaporkan kegiatan perlindungan dan pengamanan hutan serta peredaran hasil hutan (Sukarman, 2018). Dengan demikian penelitian ini penting untuk dilakukan bertujuan untuk menganalisis temuan patroli polisi hutan dalam melindungi satwa liar dari perburuan di TNWK.

\section{METODE}

Penelitian ini dilaksanakan di Resort Way Kanan, TNWK, Kabupaten Lampung Timur, Lampung pada bulan September 2020. Alat dan bahan yang digunakan dalam penelitian ini yaitu kamera untuk mengambil gambar, GPS (Garmin), recorder (Hp) digunakan sebagai perekam saat wawancara bersama polisi hutan, laptop (Dell) sebagai alat bantu meng input data, kuesioner digunakan untuk mengumpulkan informasi. Obyek penelitian pada penelitian ini yaitu temuan patroli polisi hutan yang melindungi satwa liar dari perburuan di TNWK. Pengumpulan data dilakukan dengan observasi dan wawancara menggunakan kuesioner ataupun studi literatur 4 tahun terakhir di TNWK. Responden yang dipilih untuk wawancara terdiri dari polisi hutan sebanyak enam orang dan pengelola TNWK sebanyak sepuluh orang dengan metode Snowball Sampling. Data yang terkumpul dianalisis secara deskriptif kualitatif untuk menganalisis optimalisasi patroli hutan dalam melindungi satwa liar dari perburuan di TNWK. Peta lokasi penelitian dapat dilihat pada Gambar 1. 


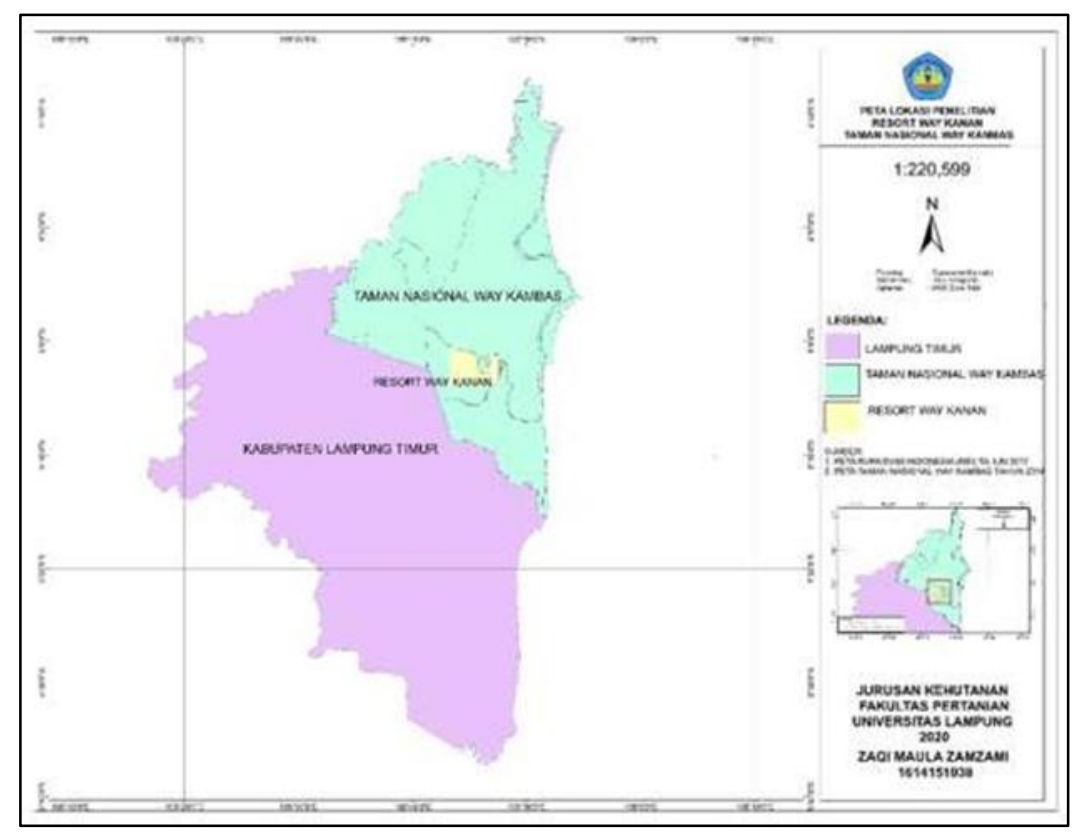

Gambar 1. Peta lokasi penelitian Resort Way Kanan, Taman Nasional Way Kambas Figure 1. Map of the research location of Way Kanan Resort, Way Kambas National Park

\section{HASIL DAN PEMBAHASAN}

\section{A. Kondisi Lokasi Penelitian}

Way Kanan termasuk ke dalam wilayah Resort Pengelolaan TNWK. Way Kanan termasuk ke dalam Seksi 1 atau SPTN 1 Way Kanan. Berjarak kurang lebih $13 \mathrm{~km}$ dari pintu gerbang masuk Plang ljo dan terhubung oleh jalan darat yang sebagian beraspal. Resort Way Kanan relatif mudah dijangkau dengan menempuh waktu selama 20 - 30 menit menggunakan kendaraan roda dua atau kendaraan roda empat.

Sebelum tiba di Resort Way Kanan, dalam perjalan dari Plang ljo dapat dinikmati suasana hutan dataran rendah sepanjang jalan. Sesekali akan terdengar suara siamang ataupun melihat langsung sedang bergelantungan diatas pohon. Selain itu dapat pula bertemu dengan penghuni hutan lainnya seperti rusa sambar (Cervus unicolor), napuh (Tragulus napu), berbagai jenis kupu - kupu dan ayam hutan (Gallus gallus).

Resort Way Kanan TNWK terletak pada zona inti. Zona inti merupakan bagian yang mempunyai kondisi alam yang asli dan belum terganggu oleh manusia. Berfungsi sebagai perlindungan ekosistem, pengawetan flora dan fauna beserta habitatnya dan sumber plasma nutfah dari jenis tumbuhan dan satwa liar. Selain itu Resort Way Kanan juga cocok dijadikan sebagai wisata minat khusus karena di dalamnya terdapat satwa - satwa yang dilindungi (Febryano dan Rusita, 2018) selain itu wisata juga dapat mendorongnya pendapatan berupa finansial untuk menunjang kegiatan konservasi (Rusita et al., 2019; Wibowo et al., 2019; Febryano et al., 2019). Penutupan lahan yang mendominasi pada zona inti adalah hutan, semak, dan alang-alang. Pada tahun 1996-2002 luasan hutan menurun dari 35.569,5 ha menjadi 29.515,8 ha, sedangkan tahun 2010 meningkat sebesar 31.386,2 ha. Perubahan tutupan lahan hutan dapat mengancam bagi kestabilan luasan hutan tiap tahunnya (Maullana dan Darmawan, 2014). Dapat dilihat pada Gambar 2. 


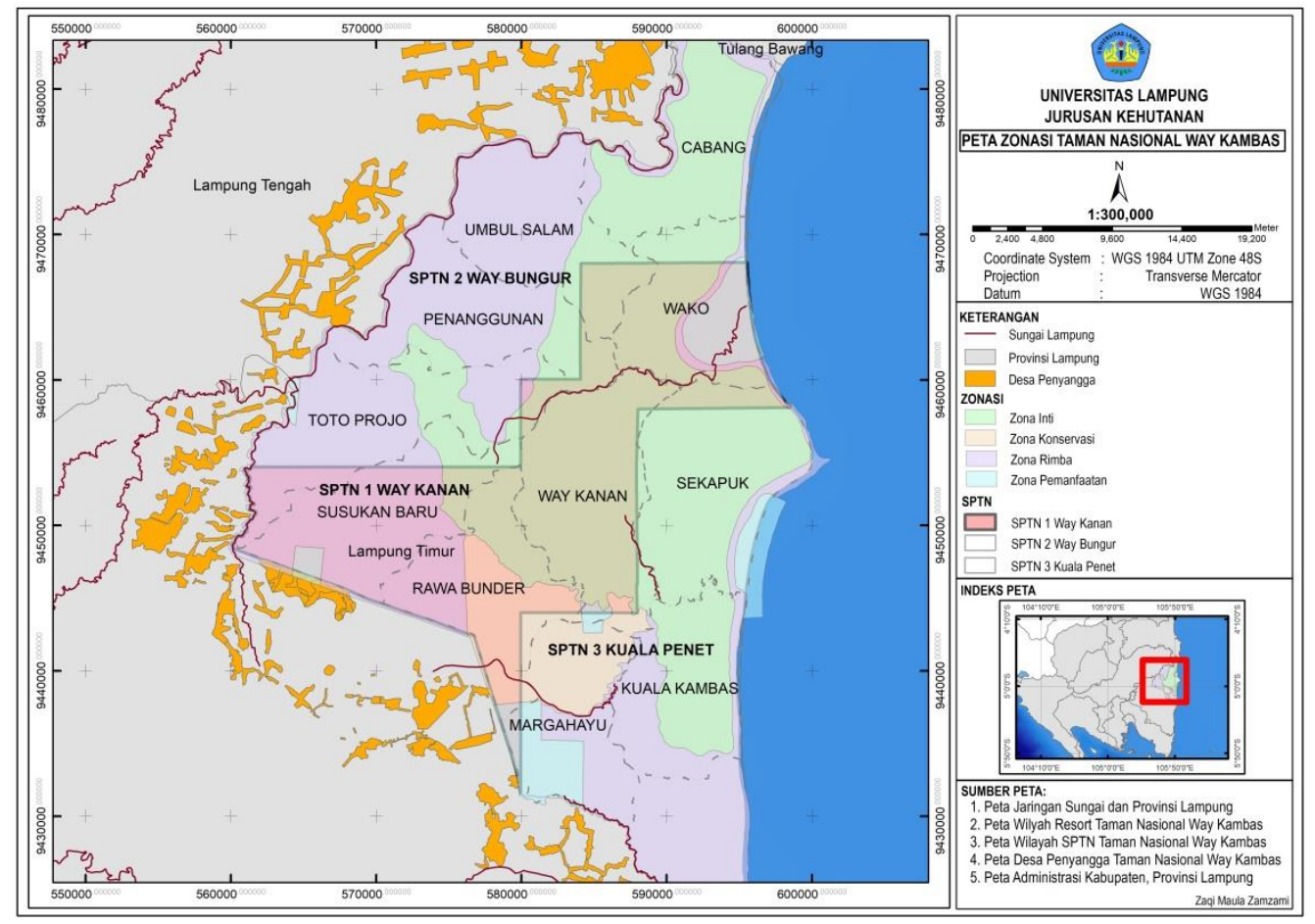

Gambar 2. Peta Zonasi Taman Nasional Way Kambas

Figure 2. Zoning Map of Way Kambas National Park

\section{B. Temuan Patroli Polisi Hutan Terhadap Perburuan Satwa}

Jumlah polisi hutan di TNWK yaitu 64 orang yang terdiri dari pekerja balai 16 orang, PLG 2 orang, SPTN I 16 orang, SPTN II 20 orang dan SPTN III 10 orang. Pada saat melakukan kegiatan patroli hutan satu tim terdiri dari minimal dua orang atau tentatif tergantung kegiatan yang dilakukan. Kegiatan patroli juga dilakukan berdasarkan hari bukan jarak sehingga petugas patroli hutan lebih mudah untuk mengetahui pergantian jadwal yang patroli selanjutnya.

Setiap tahunnya daya jelajah patroli polisi hutan di Resort Way Kanan mengalami peningkatan. Pada tahun 2016 daya jelajah yang dilakukan polisi hutan hanya $38,71 \mathrm{~km}$ dan seiring bertambahnya daya jelajah gajah yang berada di TNWK sehingga daya jelajah patroli pada tahun 2019 meningkat menjadi 2987,11 km. Daya jelajah patroli di Resort Way Kanan pada tahun 2016 sampai dengan 2019 dapat dilihat pada Gambar 3. 
Jurnal Belantara Vol. 4, No 2, Agustus 2021 (186-194)

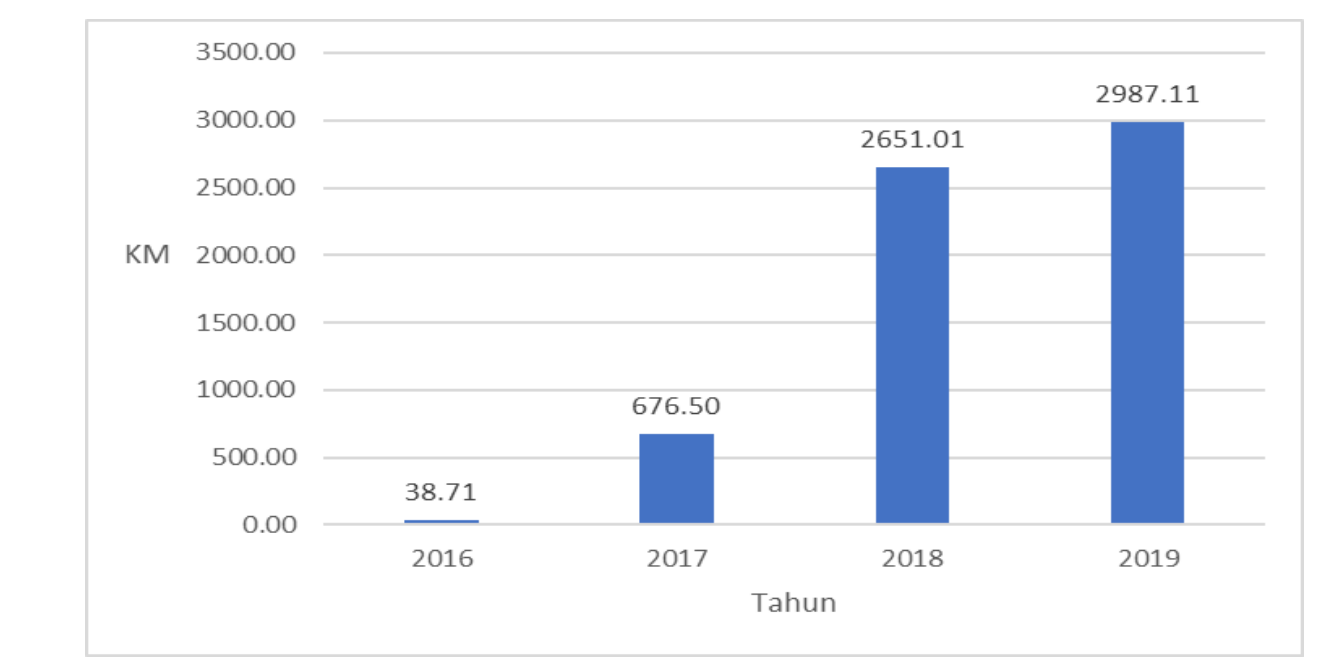

Gambar 3. Grafik daya jelajah patroli di Resort Way Kanan tahun 2016-2019 Figure 3. Graph of patrol range at Resort Way Kanan, 2016-2019

Jenis satwa yang sensitif terhadap keberadaan manusia akan cenderung menghindari perjumpaan dengan manusia, dan menjauh dari sumber gangguan pada saat mengeksploitasi hutan Adanya upaya pengusiran gajah dari area yang berdekatan dengan masyarakat menyebabkan menyempitnya habitat dan wilayah jelajah gajah yang mendorong gajah mencari ruang gerak baru (Rohman et. al., 2019).

Perlindungan dan pengamanan kawasan hutan merupakan upaya untuk meminimalisir adanya perambahan hutan, pencurian sumber daya alam hayati dan permukiman liar. Hal ini menjadi permasalahan utama yang dihadapi oleh hampir semua pengelola kawasan Taman Nasional sehingga menjadi ancaman sangat serius bagi kelestarian ekosistem kawasan (Sukarman, 2018). polisi kehutanan merupakan ujung tombak terciptanya perlindungan dan pelestarian kawasan konservasi sumber daya alam khususnya Taman Nasional.

Dalam penilaian indikator kinerja Lapangan, hal-hal yang diperhatikan yaitu kesesuaian indikator administratif terhadap laporan adanya permasalahan di lapangan dan kendala dalam pencapaian kinerja. Berdasarkan Program kerjanya, polisi Kehutanan di TNWK telah melaksanakan rencana kerjanya dan berhasil menemukan permasalahan-permasalahan di lapangan setiap tahunnya.

Beberapa permasalahan umum yang terjadi di Resort Way Kanan TNWK adalah perburuan satwa liar yaitu gajah. Menganggap bahwa tidak adanya teguran yang tegas dari petugas, hal ini menjadi sebuah pembiaran yang sudah menjadi penyakit masyarakat yang berlangsung sudah cukup lama. Setelah penemuan masalah-masalah tersebut, diberlakukan pembukuan Laporan Kejadian kemudian ditindaklanjuti sesuai dengan mekanisme Taman Nasional. Namun dalam penindaklanjutannya masih mengalami beberapa kendala yang dihadapi seperti kurang seriusnya beberapa pihak tertentu dalam menanggapi kasus dan masalah kehutanan, ini akan menyebabkan kurangnya efek jera terhadap pelaku dan akan membuat mereka melakukan kasus yang serupa dilain waktu.

Kinerja polisi hutan sangat dipengaruhi oleh faktor individu yakni karateristik dari Polhut, pendidikan dan pelatihan, faktor psikologis, dan lingkungan atau organisasi tempat polhut bekerja (Gibson et al., 2012). Berdasarkan pendapat tersebut, meyakini bahwa naik turunnya kinerja di pengaruhi oleh kemampuan dan motivasi sumber daya manusia yang maksimal disertai dengan infrastruktur yang mempunyai kemampuan teknologi yang tinggi didukung finansial yang memadai (Suzanto dan Solihin, 2012). 
Terdapat 5 jenis jerat yang berhasil ditemui oleh polisi hutan dari tahun 2016 sampai 2019 di TNWK (Balai Taman Nasional Way Kabas. 2020). Jerat tersebut di gunakan oleh pemburu untuk menjerat berbagai jenis satwa liar. Diketahui paling banyak ditemukannya jerat jala kabut yaitu pada tahun 2016 dan mengalami penurunan pada tahun 2019 yang dapat dilihat pada Gambar 4.

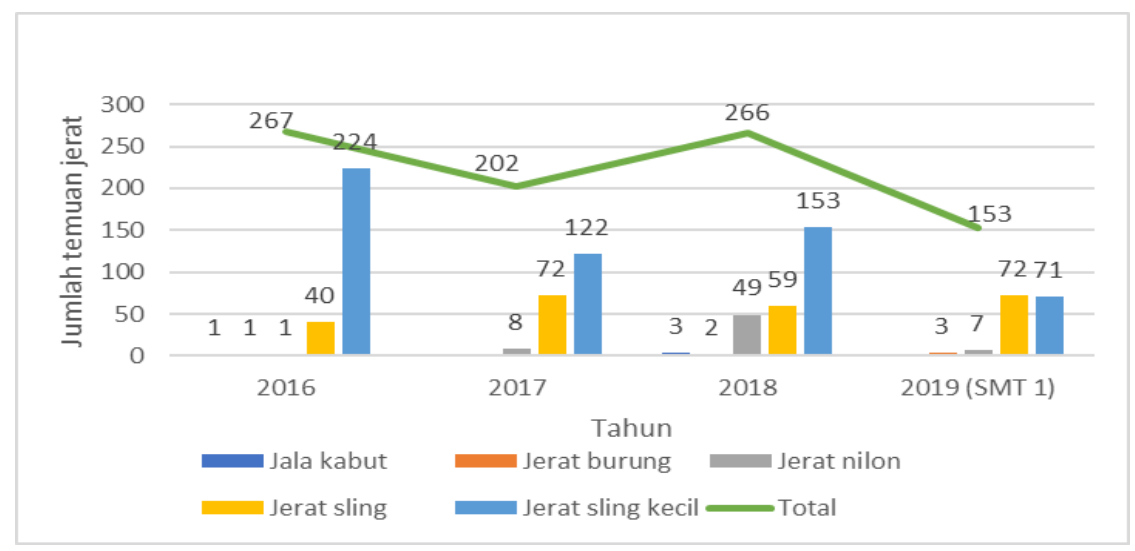

Gambar 4. Jumlah temuan jerat tahun 2016 - 2019 di SPTN 1 Way Kanan TNWK

Figure 4. Number of snares found in 2016 - 2019 at SPTN 1 Way Kanan TNWK

Pada penelitian ini ditemukan 5 jenis jerat yang sering digunakan masyarakat untuk menangkap satwa liar. Jenis-jenis jerat yang dapat dikategorikan berdasarkan cara kerja yaitu:

1. Jerat seling atau seling kecil adalah jerat yang digunakan untuk mamalia jerat diletakkan pada jalur satwa, kemudian pemburu menghalau satwa ke arah jerat tersebut.

2. Jerat nilon adalah jerat yang terbuat dari tali nilon jerat ini biasanya digunakan pemburu untuk menjerat mamalia besar seperti gajah, harimau atau badak. Organ sasaran kaki: pada saat satwa menginjak "dudukan", kait terlepas dari tempat kaitan sehingga tali mengikat kaki.

3. Jerat burung adalah jerat untuk burung, tidak memiliki pelontar, cara kerja jeratburung adalah tali yang sudah dibentuk diikatkan pada kayu, ketika leher satwa melewati jerat tali yang sudah dibentuk maka leher satwa akan terikat.

4. Jerat jala kabut adalah jerat yang terbuat dari tali nilon untuk menangkap burung, jaring dipasang dekat umpan, ketika burung melewati jaring, tubuhnya tergulung ke dalam jaring.

Jerat yang paling banyak ditemukan diketahui adalah jerat jala kabut dikarenakan burung memiliki harga jual yang cukup tinggi dengan permintaan pasar yang cukup banyak. Menurut Mukhtar (2004) terdapat 406 jenis burung di TNWK yaitu bebek hutan (Cairina scutulata), bangau sandang lawe (Ciconia episcopus), bangau tong-tong (Leptoptilos javanicus), sempi dan biru (Lophura ignita), kuau (Argusianus argus argus), pecuk ular (Anhinga melanogaster); berbagai jenis reptilia, amfibia, ikan, dan insekta.

Pengelolaan kawasan hutan di TNWK kurang efektif karena pengelolaan yang dilakukan belum mencapai tujuan yang ditetapkan mengingat luasnya kawasan hutan yang dikelola dan banyaknya permasalahan gangguan terhadap kawasan hutan. Penyelenggaraan pengamanan kawasan konservasi berbasis masyarakat didasarkan pada pemahaman bahwa untuk menciptakan kondisi aman dan tertib tidak hanya dilakukan oleh Polhut melainkan juga melibatkan masyarakat yang selama ini menjadi obyek (Sukarman, 2018).

Jumlah gajah yang mati di Resort Way Kanan pada tahun 2018 sampai dengan tahun 2019 berjumlah 4 ekor dengan penyebab kematian yang beragam seperti perburuan ataupun karena 
faktor usia yang sudah tua. Daftar lengkap terkait informasi gajah yang ditemukan mati dapat dilihat pada tabel 1.

Tabel 1. Informasi kematian gajah di Resort Way Kanan Taman Nasional Way Kambas

Table 1. Information on elephant deaths at Way Kambas National Park Resort Way Kanan

\begin{tabular}{|c|c|c|c|c|c|c|}
\hline No & Waktu & $\begin{array}{c}\text { Tipe } \\
\text { Kematian }\end{array}$ & Penyebab & Jumlah & $\begin{array}{l}\text { Jenis } \\
\text { Kelamin }\end{array}$ & Kondisi \\
\hline 1 & $7-08-2018$ & Ilegal & Perburuan & 1 & Betina & $\begin{array}{lr}\text { Masih anakan, } & \text { and } \\
\text { membusuk pada } \\
\text { bagian } & \text { tubuh } \\
\text { tertentu dengan } \\
\text { gading } \\
\text { hilang yang }\end{array}$ \\
\hline 2 & 7-08-2018 & Ilegal & Perburuan & 1 & Betina & $\begin{array}{l}\text { Dewasa, } \\
\text { membusuk pada } \\
\text { bagian tubuh } \\
\text { tertentu dengan } \\
\text { gading yang } \\
\text { hilang }\end{array}$ \\
\hline 3 & $21-07-2019$ & Alami & Penyakit & 1 & $\begin{array}{l}\text { Tidak } \\
\text { diketahui }\end{array}$ & $\begin{array}{l}\text { Tersisa kerangka } \\
\text { dengan gading } \\
\text { yang hilang }\end{array}$ \\
\hline 4 & $26-08-2019$ & $\begin{array}{l}\text { Tidak } \\
\text { diketahui }\end{array}$ & $\begin{array}{l}\text { Tidak } \\
\text { diketahui }\end{array}$ & 1 & $\begin{array}{l}\text { Tidak } \\
\text { diketahui }\end{array}$ & $\begin{array}{l}\text { Tersisa kerangka } \\
\text { dengan gading } \\
\text { yang hilang }\end{array}$ \\
\hline
\end{tabular}

Sumber: Data primer (2020).

TNWK memiliki kekayaan hayati dan nonhayati yang yang sangat besar (Marcelina et. al., 2018) sehingga ditetapkannya sebagai kawasan pelestarian alam untuk melindungi kawasan yang kaya akan berbagai satwa liar salah satunya gajah Sumatera (Elephas maximus sumatranus). Untuk bertahan hidup gajah memiliki syarat minimal yaitu ketersediaan air untuk mandi, minum, dan berkubang, garam mineral, naungan vegetasi (Meytasari et al., 2014).

Aktivitas yang memicu penurunan polulasi satwa liar yaitu perburuan satwa, satwa liar banyak diperdagangkan secara langsung, diburu dan dimanfaatkan anggota tubuhnya (Alikodra, 1990). Gangguan manusia berupa penyempitan habitat dan perburuan dapat menyebabkan penurunan populasi satwa liar secara drastis atau wilayah teritorial satwa liar semakin sempit sehingga intensitas penurunan populasi satwa semakin meningkat dari tahun ketahun (Nugroho et al., 2008). keanekaragakan satwa yang beragam, jenis satwa yang hidup di TNWK antara lain ialah badak Sumatra (Dicerorhinos sumatrensis), gajah Sumatra (Elephas maximus sumatranus), harimau Sumatra (Panthera tigris sumatrae), tapir (Tapirus indicus), anjing hutan (Cuon alpinus sumatrensis), jenis primata seperti siamang (Hylobates syndactylus) (Balai Taman Nasional Way Kambas, 2006).

Perburuan yang dilakukan masyarakat juga tidak mengenal usia gajah yang akan dijadikan buruan, dan biasanya masyarakat memburu menggunakan senapan yang mengakibatkan gajah tersebut mati dan membusuk pada bagian tubuh tertentu. Bagian yang diambil biasanya hanya gading gajah karena diketahui harga gading gajah pada pasar ilegal terbilang cukup tinggi sehingga masyarakat masih banyak yang ingin memburu gajah dengan resiko yang mungkin akan merugikan pemburu tersebut. 
Menurut Prayudhi (2015) perburuan dan perdagangan satwa liar merupakan bentuk eksploitasi sumber daya alam tanpa memperhatikan kelestarian lingkungan. Kerusakan lingkungan ini telah mengganggu proses alam, sehingga banyak fungsi ekologi alam terganggu. Masalah konservasi sumber daya alam tidak berdiri sendiri, tetapi selalu saling terkait erat. Keterkaitan antara masalah satu dengan yang lain disebabkan karena sebuah faktor merupakan sebab berbagai masalah, sebuah faktor mempunyai pengaruh yang berbeda dan interaksi antar berbagai masalah dan dampak yang ditimbulkan bersifat kumulatif.

Kendala-kendala yang dihadapi secara spesifik adalah masyarakat sekitar kawasan TNWK yang mana beberapa dari mereka masih mengabaikan peraturan-peraturan kehutanan, seperti menebang beberapa pohon dalam kawasan hutan untuk dijadikan kebun atau ladang dan ada masih banyaknya perburuan liar yang susah dijangkau oleh polisi kehutanan. Yang menjadi perhatian yaitu, apabila telah dilakukan penyuluhan dan beberapa teguran dari satgas polisi Kehutanan mereka tetap melakukan beberapa hal yang serupa.

\section{SIMPULAN DAN SARAN}

Pelaksanaan polisi hutan dalam melakukan patroli di Resort Way Kanan TNWK dengan fungsi polhut sebagai pencegah perburuan terhadap satwa dirasa belum optimal karena fakta di lapangan masih cukup banyak perburuan menggunakan jerat walaupun temuan jerat dan daya jelajah terbilang cukup baik tetapi masih ditemukannya satwa gajah yang mati akibat perburuan. Untuk lebih memaksimalkan pencapaian kerja tugas pokok, fungsi dan wewenang polhut, perlu dijalin kerjasama dan koordinasi yang intensif antara TNWK, masyarakat dan Mitra selain itu penambahan fasilitas sarana dan prasarana terkait untuk kegiatan patroli.

\section{UCAPAN TERIMA KASIH}

Terima kasih yang sebesar besarnya saya ucapkan kepada pihak Balai Taman Nasiona Way Kambas yang telah memfasilitasi dalam pengambilan data penelitian.

\section{DAFTAR PUSTAKA}

Alikodra, H.S. (1990). Pengelolaan satwa liar jilid I. Departemen Pendidikan dan Kebudayaan Direktorat Jendral Pendidikan Tinggi. Pusat Antar Universitas Ilmu Hayati. IPB. Bogor.

Zain, A.S (2000). Hukum lingkungan konservasi hutan. Rineka Cipta, Jakarta.

Sunarto, A. (2013). Potret pendidikan masyarakat tradisional, modern, dan era globalisasi. Jurnal Aktual, 1 (1).

Balai Taman Nasional Way Kambas. (2006). Flora dan fauna di Taman Nasional Way Kambas. Laporan Rencana Pengelolaan TNWK 2006-2025. Buku. Bandar Lampung. 78 hlm.

Direktorat Jenderal Perlindungan Hutan dan Konservasi Alam. (2011). Buku saku polisi kehutanan. Direktorat Jenderal Perlindungan Hutan dan Konservasi Alam. Jakarta.

Febryano, I.G. \& Rusita. (2018). Persepsi wisatawan dalam pengembangan wisata pendidikan berbasis konservasi gajah sumatera (Elephas maximus sumatranus). Jurnal Pengelolaan Sumber daya Alam dan Lingkungan, 8(3), 376-382.

Febryano, I.G., Rusita., Banuwa, I.S., Marcelina, S.D., Subakir. \& Krismuniarti, E.D. (2019). Determining the sumatran elephant (Elephas maximus sumatranus) carrying capacity in Elephant Training Centre, Way Kambas National Park, Indonesia. Foresty Ideas, 25(1), 1019. 
Gibson, J.L., Ivanchevich, J \& Donnelly, J.H. (2012). Organization: Behaviour, structure, processes.14th edition. New York: McGraw-Hill Companies, Inc.

Mallawi, A. (2010). Populasi dan keanekaragaman spesies reptil di hutan alam pada hutan pendidikan Fakultas Kehutanan Unhas (Skripisi). Makassar: Program Studi Kehutanan, Fakultas Kehutanan. Tidak diterbitkan.

Marcelina, S.D., Febryano, I.G., Setiawan, A. \& Yuwono, S.B. (2018). Persepsi wisatawan terhadap fasilitas wisata di Pusat Latihan Gajah Taman Nasional Way Kambas. Jurnal Belantara,1(2), 45-53.

Maullana, D.A. \& Darmawan, A. (2014). Perubahan penutupan lahan di Taman Nasional Way Kambas. Jurnal Sylva Lestari, 2(1), 87-94.

Meytasari, P., Bakri, S. \& Herwanti, S. (2014). Penyusunan kriteria domestikasi dan evaluasi praktek pengasuhan gajah: Studi di Taman Nasional Way Kambas Kabupaten Lampung Timur. Jurnal Sylva Lestari, 2(2), 79-88.

Mukhtar. (2004). Taman Nasional Way Kambas daya tarik kepariwisataan Lampung. E-USU Repository Universitas Sumatera Utara, 1(2), 1-10.

Nugroho, Pandam. \& Sukandar, P. (2008). Distribusi jenis kelelawar (Pteropodidae) pada berbagai tipe penutupanan lahan di sekitar kawasan Taman Nasional Kerinci Seblat (TNKS). Jurnal Biologi Indonesia, 5(2), 121-135.

Pratiwi, P., Rahayu, S.P. Rizaldi, A., Iswandaru, D. \& Winarno, W.D. (2020). Persepsi masyarakat terhadap konflik manusia dan gajah sumatra (Elephas maximus sumatranus Temminck 1847) di Taman Nasional Way Kambas. Jurnal Sylva Lestari, 8(1), 98-108.

Prayudhi. (2015). Penegakan hukum, rehabilitasi dan pelepasliaran satwa dilindungi hasil sitaan negara ujung tombak upaya penstabilan ekosistem kawasan konservasi. 17 maret 2020, diunduh dari, https://www.researchgate.net/publication/307953979.

Sukarman. (2017). Faktor pendukung dan peran brigade pengendalian kebakaran hutan pada Balai Taman Nasional Way Kambas. Jurnal Sylva Lestari, 5(3), 104-115.

Sukarman. (2018). Partisipasi masyarakat Mitra Polhut pada upaya perlindungan dan pengamanan hutan di Taman Nasional Way Kambas. Jurnal Sylva Lestari, 6(1), 85-98.

Sugiyono. (2007). Metode penelitian kuantitatif kualitatif dan R\&D. Alfabeta. Bandung.

Suzanto, B. \& Ari, S. (2012). Pengaruh budaya organisasi, komunikasi interpersonal dan komitmen organisasi terhadap kinerja pegawai pada unit network management system infratel PT Telekomunikasi Indonesia Tbk. Jurnal Ekonomi Bisnis dan Enterpreneurship, $6(2)$.

Rohman, W.A., Darmawan, A., Wulandari, C. \& Dewi, B.S. (2019). Preferensi jelajah harian gajah sumatera (Elephas maximus sumatranus) di Taman Nasional Bukit Barisan Selatan. Jurnal Sylva Lestari, 7(3), 309-320.

Rusita., Febryano, I.G., Banuwa, I.S. \& Yuwono, S.B., (2019). Potensi hutan rawa air tawar sebagai alternatif ekowisata berbasis konservasi gajah sumatera (Elephas maximus sumatranus). Jurnal Pengelola Sumber daya Alam dan Lingkungan, 9(2), 498-506.

Wibowo, I.P., Herwanti, S., Febryano, I.G. \& Winarno, G.D. (2019). Nilai ekonomi Pusat Latihan Gajah di Taman Nasional Way Kambas. Jurnal Hutan Tropis, 7(1), 18-24. 